\title{
Sandwich Intermediate Sitting-atop Complexation between Free Base meso-tetraarylporphyrins and Tellurium(IV) chloride
}

\author{
Hossein Dehghani, 'Sara Bakhshayesh, Maryam Shaterian, and Leila Motamedi \\ Department of Inorganic Chemistry, Faculty of Chemistry, University of Kashan, Kashan, 87317-51167, Iran \\ *E-mail: Dehghani@kashanu.ac.ir \\ Received October 23, 2009, Accepted December 21, 2009
}

\begin{abstract}
Free base meso-tetraarylporphyrins $\left(\mathrm{H}_{2} \mathrm{~T}(\mathrm{X}) \mathrm{PP}\right)$ react with tellurium(IV) chloride $\left(\mathrm{TeCl}_{4}\right)$ in mild conditions for formation sandwich intermediate sitting-atop (i-SAT) complexes, $\left[\mathrm{TeCl}_{4}\left(\mathrm{H}_{2} \mathrm{~T}(\mathrm{X}) \mathrm{PP}\right)_{2}\right] .{ }^{1} \mathrm{H} \mathrm{NMR},{ }^{13} \mathrm{C} \mathrm{NMR}, \mathrm{UV}$-vis, FT-IR and elemental analysis were used for characterization of the products. In the proposed structure of the i-SAT complexes, four pyrroles of each porphyrin ring are tilted alternatively up and down and this appropriates suitable orientation of lone pairs of two pyrrolenine nitrogens for electron donation to a tellurium center. ${ }^{1} \mathrm{H}$ NMR and FT-IR results showed that in the produced complex, hydrogen atoms of porphyrin macrocycles remained on the pyrrole nitrogens.
\end{abstract}

Key Words: i-SAT complex, Porphyrin, Tellurium(IV) chloride, Deformation

\section{Introduction}

Porphyrins are a class of biochemically and biologically important compounds that have found a broad spectrum of applications in different fields such as catalysis, medicine, and materials. ${ }^{1}$ Intermediate sitting-atop (i-SAT) complexes have very short life-time and have been proposed as intermediate in metallation of porphyrins. It has been reported that porphyrins are capable of forming intermediate sitting-atop (i-SAT) complexes $^{2-7}$ or 1:1 (donor:acceptor) molecular complexes with different electron acceptors. ${ }^{8,9}$ Antimony(III) chloride and bismuth(III) chloride react with meso-tetraarylporphyrins for formation of dimer molecular complexes with 1:1 mole ratio, $\left[\mathrm{MCl}_{3}\left(\mathrm{H}_{2} \mathrm{~T}(\mathrm{X})\right.\right.$ $\left.\mathrm{PP})_{2}\right](\mathrm{M}=\mathrm{Sb}, \mathrm{Bi}) .{ }^{8,9}$ Newly, we have reported the sandwich i-SAT complexes from reaction between $\mathrm{GeCl}_{4}$ with meso-tetraarylporphyrins. ${ }^{10}$ In the i-SAT complexes, the tilted porphyrin core gives two lone pairs of pyrrolenine nirtogens to a central atom of the acceptors and so four aryl rings contributed in the resonance of the porphyrin core and in result produced large $\pi$ electron delocalization in the complexed porphyrins. This article presents synthesis of novel sandwich intermediate sitting-atop (i-SAT) complexes of several meso-tetraarylporphyrins (Figure 1) and $\mathrm{TeCl}_{4}$. Tellurium(IV) chloride has four chlorine atoms with high electron withdrawing effect for acceptation of four lone pairs of two distorted porphyrin macrocycle for formation of sandwich i-SAT complexes, Figure 2.

\section{Experimental}

Benzaldehyde, various substituted benzaldehydes $\left(3-\mathrm{CH}_{3}\right.$, 4- $\mathrm{CH}_{3}, 3-\mathrm{OCH}_{3}, 4-\mathrm{OCH}_{3}$, 4-isoprophyl) and $\mathrm{TeCl}_{4}$ obtained from Merck and were used without further purification. Pyrrole purchased from Merck and distilled before used. Chloroform (Merck) was dried over anhydrous calcium chloride for 3 days and then distilled before use. Other solvent that were employed for the synthesis of the porphyrins and molecular complexes were obtained from Merck and Fluka, and were used as received. The meso-tetraarylporphyrins were prepared by the literature

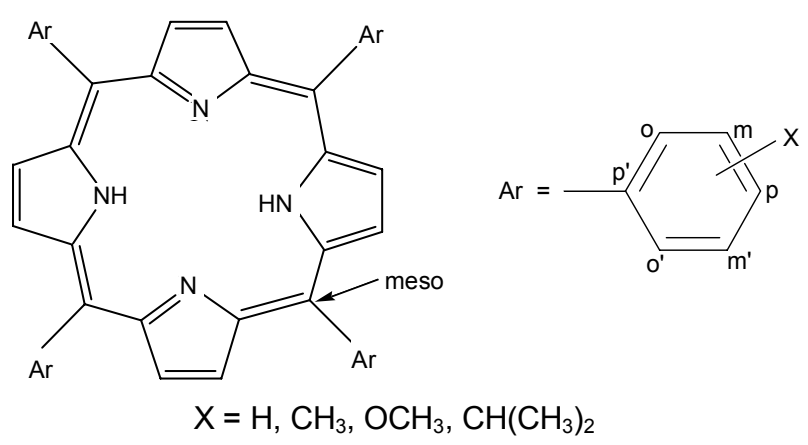

Figure 1. Meso-tetraarylporphyrins, $\mathrm{H}_{2} \mathrm{~T}(\mathrm{X}) \mathrm{PP}$

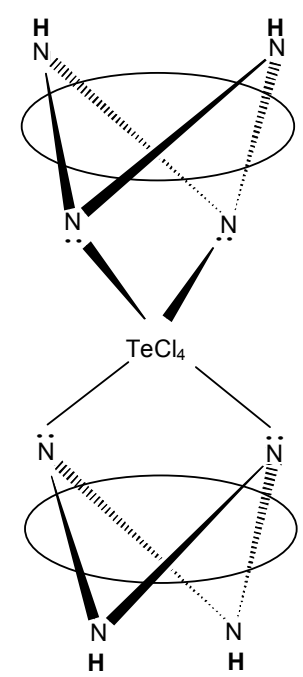

Figure 2. Two saddled porphyrins cores act as electron donors to a tellurium(IV) atom of $\mathrm{TeCl}_{4}$.

methods. ${ }^{11}$

The NMR spectra $\left({ }^{1} \mathrm{H}\right.$ and $\left.{ }^{13} \mathrm{C}\right)$ were recorded on a Bruker 400 Ultrashield spectrometer in $\mathrm{CDCl}_{3}$. The residual $\mathrm{CHCl}_{3}$ in the conventional $99.8 \%$ atom $\mathrm{CDCl}_{3}$ gives a signal at $\delta=7.26$ 
ppm, which was used for calibration of the chemical shift scale. FT-IR spectra were recorded on a Magna 550 Nicolet spectrometer using $\mathrm{KBr}$ pellets. The UV-vis measurements were obtained with a GBC cintra $6 \mathrm{UV}$-vis spectrophotometer. The molar conductance was measured on a METROHM 644 conductometer.

$\mathrm{TeCl}_{4}(0.05 \mathrm{mmol})$ dissolved in $10 \mathrm{~mL}$ chloroform and added to meso-tetraarylporphyrins $(0.1 \mathrm{mmol})$ in $15 \mathrm{~mL}$ chloroform and the mixture was stirred for $20 \mathrm{~min}$. With evaporation of the solvent at room temperature obtained the green sandwich i-SAT complexes $\left(\left[\mathrm{TeCl}_{4}\left(\mathrm{H}_{2} \mathrm{~T}(\mathrm{X}) \mathrm{PP}\right)_{2}\right]\right)$. The progress of the reaction was monitored by UV-vis spectra. The mixture of two reactants did not show soret band related to the free base porphyrins, and in result the porphyrins completely change to the related sandwich i-SAT complexes. The results of elemental analyses for the sandwich i-SAT complexes which were dried under vacuum oven for $12 \mathrm{~h}$ at $50-55^{\circ} \mathrm{C}$ were obtained.

[ $\left.\mathbf{T e C l}_{4}\left(\mathbf{H}_{2} \mathbf{T}\left(4-\mathbf{O C H}_{3}\right) \mathbf{P P}\right)_{2}\right]$. $\mathrm{C}_{96} \mathrm{H}_{76} \mathrm{~N}_{8} \mathrm{O}_{8} \mathrm{TeCl}_{4}$ Anal. Calc: $\mathrm{C}$, 66.30; H, 4.40; N, 6.44\%. Found: C, 66.12; H, 4.23; N, 6.25\%. ${ }^{1} \mathrm{H} \mathrm{NMR}\left(\mathrm{CDCl}_{3}\right) \delta 0.55(\mathrm{~s}, 2 \mathrm{H}, \mathrm{NH}), \delta 4.18\left(\mathrm{~s}, 12 \mathrm{H}, \mathrm{OCH}_{3}\right)$, $\delta$ 8.54-8.56 (d, 8H, o, o'), $\delta$ 7.54-7.56 (d, 8H, m, m'), $\delta 8.50(\mathrm{~s}$, $8 \mathrm{H}, \beta)$. IR $(\mathrm{KBr}) \mathrm{v}_{\mathrm{NH}}\left(\sim 3320 \mathrm{~cm}^{-1}\right)$.

[ $\mathbf{T e C l}_{4}\left(\mathbf{H}_{2} \mathbf{T}\left(4-\mathbf{C H}_{3}\right) \mathbf{P P}\right)_{2}$ ]. $\mathrm{C}_{96} \mathrm{H}_{76} \mathrm{~N}_{8} \mathrm{TeCl}_{4}$ Anal. Calc.: C, 71.57; H, 4.75; N, 6.95\%. Found: C, 71.33; H, 4.49; N, 6.78\%. ${ }^{1} \mathrm{H} \mathrm{NMR}\left(\mathrm{CDCl}_{3}\right) \delta 0.34(\mathrm{~s}, 2 \mathrm{H}, \mathrm{NH}), \delta 2.79\left(\mathrm{~s}, 12 \mathrm{H}, \mathrm{CH}_{3}\right), \delta$ 8.50-8.52 (d, 8H, o, o'), $\delta 7.82-7.84\left(\mathrm{~d}, 8 \mathrm{H}, \mathrm{m}, \mathrm{m}^{\prime}\right), \delta 8.56(\mathrm{~s}$, $8 \mathrm{H}, \beta)$. IR $(\mathrm{KBr}) \mathrm{v}_{\mathrm{NH}}\left(\sim 3320 \mathrm{~cm}^{-1}\right)$.

[ $\left.\mathbf{T e C l}_{\mathbf{4}}\left(\mathbf{H}_{2} \mathbf{T}\left(\mathbf{4}-\mathbf{C H}\left(\mathbf{C H}_{3}\right)_{2}\right) \mathbf{P P}\right)_{2}\right] . \mathrm{C}_{112} \mathrm{H}_{108} \mathrm{~N}_{8} \mathrm{TeCl}_{4}$ Anal. Ca1c.: C, 73.29; H, 5.93; N, 6.10\%. Found: C, 73.06; H, 5.70; N, $5.98 \% .{ }^{1} \mathrm{H}$ NMR $\left(\mathrm{CDCl}_{3}\right) \delta 0.34(\mathrm{~s}, 2 \mathrm{H}, \mathrm{NH}), \delta 1.56-1.61(\mathrm{~d}$, $\left.12 \mathrm{H}, \mathrm{CH}_{3}\right), \delta 3.33-3.37(\mathrm{~s}, 4 \mathrm{H}, \mathrm{CH}), \delta 8.52-8.55\left(\mathrm{~d}, 8 \mathrm{H}, \mathrm{o}, \mathrm{o}^{\prime}\right), \delta$ 7.86-7.88 (d, 8H, m, m'), $\delta 8.53(\mathrm{~s}, 8 \mathrm{H}, \beta)$. IR (KBr) $v_{\mathrm{NH}}$ $\left(\sim 3320 \mathrm{~cm}^{-1}\right)$.

[ $\left.\mathbf{T e C l}_{4}\left(\mathrm{H}_{2} \mathbf{T P P}\right)_{2}\right] . \mathrm{C}_{88} \mathrm{H}_{60} \mathrm{~N}_{8} \mathrm{TeCl}_{4}$ Anal. Calc.: C, 70.52; H, 4.03 ; N, 7.48\%. Found: C, 70.26; H, 3.90; N, 7.37\%. ${ }^{1}$ H NMR $\left(\mathrm{CDCl}_{3}\right) \delta 0.32(\mathrm{~s}, 2 \mathrm{H}, \mathrm{NH}), \delta 8.64-8.66\left(\mathrm{~d}, 8 \mathrm{H}, \mathrm{o}, \mathrm{o}^{\prime}\right), \delta 7.99-$ 8.05 (m, 12H, p, m, m'), $\delta 8.62(\mathrm{~s}, 8 \mathrm{H}, \beta)$. IR (KBr) $v_{\mathrm{NH}}(\sim 3320$ $\left.\mathrm{cm}^{-1}\right)$.

[ $\left.\mathbf{T e C l}_{4}\left(\mathbf{H}_{2} \mathbf{T}\left(\mathbf{3}-\mathbf{C H}_{3}\right) \mathbf{P P}\right)_{2}\right] . \mathrm{C}_{96} \mathrm{H}_{76} \mathrm{~N}_{8} \mathrm{TeCl}_{4}$ Anal. Calc.: C, 71.57; H, 4.75; N, 6.95\%. Found: C, 71.38; H, $4.62 \mathrm{~N}, 6.81 \%$. ${ }^{1} \mathrm{H}$ NMR $\left(\mathrm{CDCl}_{3}\right) \delta 0.29(\mathrm{~s}, 2 \mathrm{H}, \mathrm{NH}), \delta 2.87\left(\mathrm{~s}, 12 \mathrm{H}, \mathrm{CH}_{3}\right), \delta$ 8.48 (br., $\left.8 \mathrm{H}, \mathrm{o}, \mathrm{o}^{\prime}\right), \delta$ 7.92-7.95 (t, 4H, m), $\delta 7.80-7.82$ (d, 4H, p), $\delta 8.63(\mathrm{~s}, 8 \mathrm{H}, \beta)$. IR $(\mathrm{KBr}) v_{\mathrm{NH}}\left(\sim 3320 \mathrm{~cm}^{-1}\right)$.

[ $\left.\mathbf{T e C l}_{4}\left(\mathrm{H}_{2} \mathbf{T}\left(3-\mathbf{O C H}_{3}\right) \mathbf{P P}\right)_{2}\right] . \mathrm{C}_{96} \mathrm{H}_{76} \mathrm{~N}_{8} \mathrm{O}_{8} \mathrm{TeCl}_{4}$ Anal. Calc.: C, 66.30; H, 4.40; N, 6.44\%. Found: C, 66.09; H, 4.20; N, 6.21\%. ${ }^{1} \mathrm{H} \mathrm{NMR}\left(\mathrm{CDCl}_{3}\right) \delta 0.28(\mathrm{~s}, 2 \mathrm{H}, \mathrm{NH}), \delta 4.19\left(\mathrm{~s}, 12 \mathrm{H}, \mathrm{OCH}_{3}\right), \delta$ 8.21 (br., $\left.8 \mathrm{H}, \mathrm{o}, \mathrm{o}^{\prime}\right), \delta 7.92-7.96$ (t, $\left.4 \mathrm{H}, \mathrm{m}\right), \delta 7.53-7.55$ (br., $4 \mathrm{H}$, p), $\delta 8.68(\mathrm{~s}, 8 \mathrm{H}, \beta)$. IR (KBr) $v_{\mathrm{NH}}\left(\sim 3320 \mathrm{~cm}^{-1}\right)$.

\section{Results and Discussion}

The ${ }^{1} \mathrm{H}$ NMR results for titrations of $\mathrm{H}_{2} \mathrm{~T}\left(4-\mathrm{CH}\left(\mathrm{CH}_{3}\right)_{2}\right) \mathrm{PP}$ with $\mathrm{TeCl}_{4}(1: 0.25,1: 0.5,1: 0.75$, and 1:1) showed that molar ratio of the reactants in the i-SAT complex was 1:0.5, Figure 3 . The mixture with mole ratio of 1:0.25, leaded to a superimposition of the ${ }^{1} \mathrm{H}$ NMR spectra for the porphyrin and the related i-SAT complex. Addition of excess amounts of $\mathrm{TeCl}_{4}$ beyond 1:0.5 mole ratio leads no changes in the ${ }^{1} \mathrm{H}$ NMR spectra of the
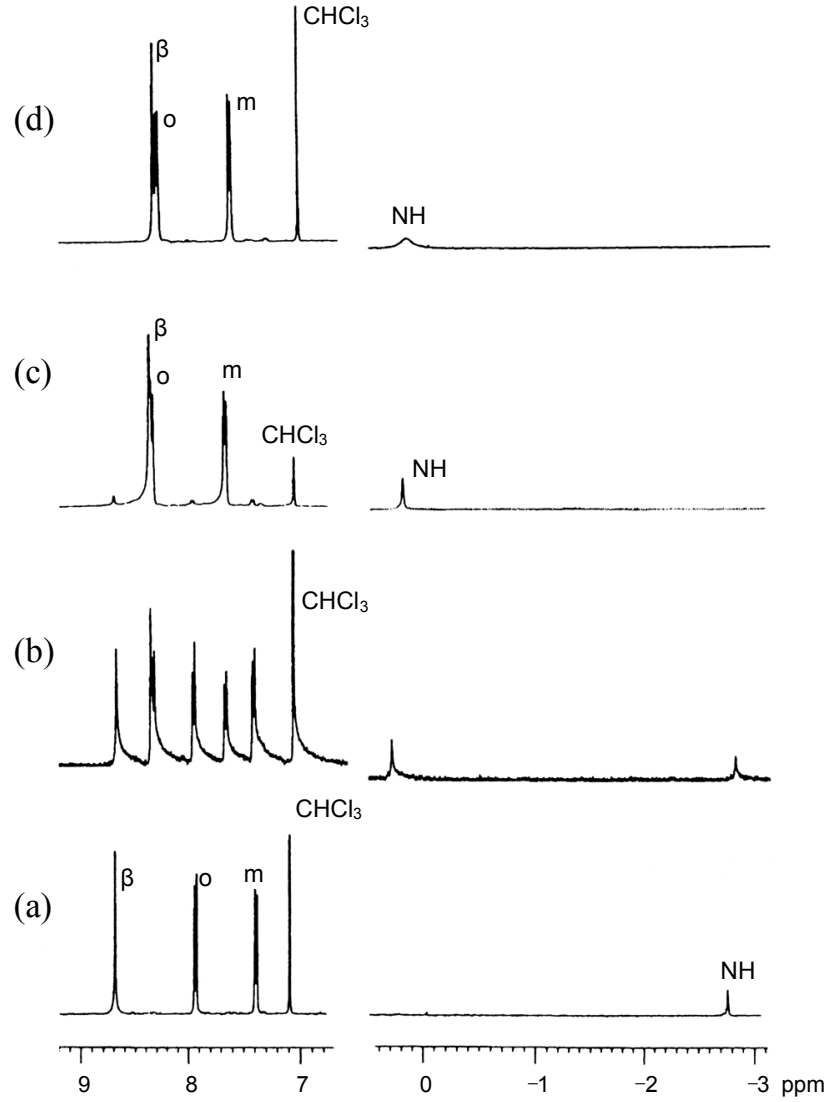

Figure 3. ${ }^{1} \mathrm{HNMR}$ spectra for the titration of $\mathrm{H}_{2} \mathrm{~T}\left(4-\mathrm{CH}\left(\mathrm{CH}_{3}\right)_{2}\right) \mathrm{PP}$ with (a) 0.0 ; (b) 0.25 ; (c) 0.5 and (d) 0.75 equivalents of $\mathrm{TeCl}_{4}$.

i-SAT complexes. Consequently, the molar ratio of porphyrin: $\mathrm{TeCl}_{4}$ was 1:0.5 and the complex had a sandwich structure. The ${ }^{1} \mathrm{H}$ NMR titration was completely supported by UV-vis spectral results too.

In the free base $\mathrm{H}_{2} \mathrm{~T}\left(4-\mathrm{CH}_{3}\right) \mathrm{PP}$ the $\mathrm{N}-\mathrm{H}$ protons are upfield $(-2.77 \mathrm{ppm}$, singlet), and the $\beta$-protons appear in $8.86 \mathrm{ppm}$ (singlet). Two doublet have been shown for the aryl rings of the $\mathrm{H}_{2} \mathrm{~T}\left(4-\mathrm{CH}_{3}\right) \mathrm{PP}$, one for the meta-protons (7.27 - $\left.7.31 \mathrm{ppm}\right)$ and another for the ortho protons (8.11 - $8.14 \mathrm{ppm})$. The i-SAT complexation of $\mathrm{H}_{2} \mathrm{~T}\left(4-\mathrm{CH}_{3}\right) \mathrm{PP}$ with tellurium (IV) chloride, similar to the complexation of the meso-tetraarylporphyrins with various electron acceptors ${ }^{2-10}$ caused an upfield shift of the $\beta$-hydrogens, and so downfield shifts for the proton signals of $\mathrm{N}-\mathrm{H}$ and aryl rings $\left(\delta 0.34(\mathrm{~s}, 2 \mathrm{H}, \mathrm{NH}), \delta 2.79\left(\mathrm{~s}, 12 \mathrm{H}, \mathrm{CH}_{3}\right), \delta\right.$ 8.50 - $8.52\left(\mathrm{~d}, 8 \mathrm{H}, \mathrm{o}, \mathrm{o}^{\prime}\right), \delta 7.82-7.84\left(\mathrm{~d}, 8 \mathrm{H}, \mathrm{m}, \mathrm{m}^{\prime}\right), \delta 8.56(\mathrm{~s}, 8 \mathrm{H}$, $\beta)$. The pyrrolic NH and $\beta$-proton chemical shifts for the porphyrins and the related i-SAT complexes and the difference of the chemical shifts upon the i-SAT complexation are listed in Table 2. These results show that the effect of ring current have been lost in the complexed porphyrin. ${ }^{2-10,12-18}$ Further, the observed downfield shifts of the aryl ring hydrogens could result from a direct increase in ring current of aryl groups. This has been produced by extension in the $\pi$-system of the aryl rings. ${ }^{2-17}$ In the i-SAT complexes the pyrrole rings are not equivalent and in result existence of a singlet for $\beta$-protons of meso-tetraarylporphyrin is not corresponding with unsymmetrical pyrrole rings in the proposed structure of the i-SAT complexes, Figure 2. This sym- 
Table 1. ${ }^{1} \mathrm{H}$ NMR spectral data of different meso-tetraarylporphyrins and the related sandwich i-SAT complexes.

\begin{tabular}{|c|c|c|}
\hline Compounds & $\mathrm{N}-\mathrm{H}$ & $\mathrm{H}_{\beta}$ \\
\hline $\begin{array}{l}\mathrm{H}_{2} \mathrm{TPP} \\
{\left[\mathrm{TeCl}_{4}\left(\mathrm{H}_{2} \mathrm{TPP}\right)_{2}\right]} \\
\Delta \delta\end{array}$ & $\begin{array}{r}-2.76 \\
0.32 \\
3.08\end{array}$ & $\begin{array}{r}8.85 \\
8.62 \\
-0.23\end{array}$ \\
\hline $\begin{array}{l}\mathrm{H}_{2} \mathrm{~T}\left(4-\mathrm{CH}_{3}\right) \mathrm{PP} \\
{\left[\mathrm{TeCl}_{4}\left(\mathrm{H}_{2} \mathrm{~T}\left(4-\mathrm{CH}_{3}\right) \mathrm{PP}\right)_{2}\right]} \\
\Delta \delta\end{array}$ & $\begin{array}{r}-2.77 \\
0.34 \\
3.11\end{array}$ & $\begin{array}{r}8.85 \\
8.56 \\
-0.29\end{array}$ \\
\hline $\begin{array}{l}\mathrm{H}_{2} \mathrm{~T}\left(3-\mathrm{CH}_{3}\right) \mathrm{PP} \\
{\left[\mathrm{TeCl}_{4}\left(\mathrm{H}_{2} \mathrm{~T}\left(3-\mathrm{CH}_{3}\right) \mathrm{PP}\right)_{2}\right]} \\
\Delta \delta\end{array}$ & $\begin{array}{r}-2.75 \\
0.29 \\
3.04\end{array}$ & $\begin{array}{r}8.88 \\
8.63 \\
-0.25\end{array}$ \\
\hline $\begin{array}{l}\mathrm{H}_{2} \mathrm{~T}\left(4-\mathrm{OCH}_{3}\right) \mathrm{PP} \\
{\left[\mathrm{TeCl}_{4}\left(\mathrm{H}_{2} \mathrm{~T}\left(4-\mathrm{OCH}_{3}\right) \mathrm{PP}\right)_{2}\right]} \\
\Delta \delta\end{array}$ & $\begin{array}{r}-2.75 \\
0.55 \\
3.30\end{array}$ & $\begin{array}{r}8.86 \\
8.50 \\
-0.36\end{array}$ \\
\hline $\begin{array}{l}\mathrm{H}_{2} \mathrm{~T}\left(3-\mathrm{OCH}_{3}\right) \mathrm{PP} \\
{\left[\mathrm{TeCl}_{4}\left(\mathrm{H}_{2} \mathrm{~T}\left(3-\mathrm{OCH}_{3}\right) \mathrm{PP}\right)_{2}\right]} \\
\Delta \delta\end{array}$ & $\begin{array}{r}-2.75 \\
0.28 \\
3.03\end{array}$ & $\begin{array}{r}8.90 \\
8.68 \\
-0.22\end{array}$ \\
\hline $\begin{array}{l}\mathrm{H}_{2} \mathrm{~T}\left(4-\mathrm{CH}\left(\mathrm{CH}_{3}\right)_{2}\right) \mathrm{PP} \\
{\left[\mathrm{TeCl}_{4}\left(\mathrm{H}_{2} \mathrm{~T}\left(4-\mathrm{CH}\left(\mathrm{CH}_{3}\right)_{2}\right) \mathrm{PP}\right)_{2}\right]} \\
\Delta \delta\end{array}$ & $\begin{array}{r}-2.74 \\
0.34 \\
3.08\end{array}$ & $\begin{array}{r}8.86 \\
8.53 \\
-0.33\end{array}$ \\
\hline
\end{tabular}

$\Delta \delta$ : Chemical shifts of the proton signals for the porphyrins upon the i-SAT complexation.

Table 2. UV-vis spectral data of the different meso-tetraarylporphyrins and $\left[\mathrm{TeCl}_{4}\left(\mathrm{H}_{2} \mathrm{~T}(\mathrm{X}) \mathrm{PP}\right)\right]$ i-SAT complexes in $\mathrm{CHCl}_{3}$.

\begin{tabular}{|c|c|}
\hline Compounds & $\lambda_{\max }(\mathrm{nm})$ \\
\hline $\mathrm{H}_{2} \mathrm{TPP}$ & $416.7(\mathrm{~S}), 516.8,551.5,592.0,648.0$ \\
\hline$\left[\mathrm{TeCl}_{4}\left(\mathrm{H}_{2} \mathrm{TPP}\right)_{2}\right]$ & $444.9 \quad 660.0$ \\
\hline$\Delta \lambda^{a}$ & 28.2 \\
\hline $\mathrm{H}_{2} \mathrm{~T}\left(4-\mathrm{CH}_{3}\right) \mathrm{PP}$ & $418.3(\mathrm{~S}), 518.4,554.0,593.0,649.0$ \\
\hline$\left[\mathrm{TeCl}_{4}\left(\mathrm{H}_{2} \mathrm{~T}\left(4-\mathrm{CH}_{3}\right) \mathrm{PP}\right)_{2}\right]$ & $447.1(\mathrm{~S}) \quad 669.4$ \\
\hline$\Delta \lambda^{a}$ & $28.8 \quad 20.4$ \\
\hline $\mathrm{H}_{2} \mathrm{~T}\left(3-\mathrm{CH}_{3}\right) \mathrm{PP}$ & $418.2(\mathrm{~S}), 517.5,550.6,590.0,647.2$ \\
\hline$\left[\mathrm{TeCl}_{4}\left(\mathrm{H}_{2} \mathrm{~T}\left(3-\mathrm{CH}_{3}\right) \mathrm{PP}\right)_{2}\right]$ & $446.2(\mathrm{~S})$ \\
\hline$\Delta \lambda^{a}$ & 28.0 \\
\hline $\mathrm{H}_{2} \mathrm{~T}\left(4-\mathrm{OCH}_{3}\right) \mathrm{PP}$ & $419.5(\mathrm{~S}), 520.5,557.1,596.0,653.0$ \\
\hline$\left[\mathrm{TeCl}_{4}\left(\mathrm{H}_{2} \mathrm{~T}\left(4-\mathrm{OCH}_{3}\right) \mathrm{PP}\right)_{2}\right]$ & $453.5(\mathrm{~S}) \quad 688.6$ \\
\hline$\Delta \lambda^{a}$ & $34.0 \quad 35.6$ \\
\hline $\mathrm{H}_{2} \mathrm{~T}\left(3-\mathrm{OCH}_{3}\right) \mathrm{PP}$ & $418.9(\mathrm{~S}), 517.0,550.3,590.3,646.6$ \\
\hline$\left[\mathrm{TeCl}_{4}\left(\mathrm{H}_{2} \mathrm{~T}\left(3-\mathrm{OCH}_{3}\right) \mathrm{PP}\right)_{2}\right]$ & $450.9(\mathrm{~S}) \quad 660.0$ \\
\hline$\Delta \lambda^{a}$ & $32.0 \quad 13.4$ \\
\hline $\mathrm{H}_{2} \mathrm{~T}\left(4-\mathrm{CH}\left(\mathrm{CH}_{3}\right)_{2}\right) \mathrm{PP}$ & 419.7(S), 519.2, 555.1, 594.4, 650.4 \\
\hline$\left[\mathrm{TeCl}_{4}\left(\mathrm{H}_{2} \mathrm{~T}\left(4-\mathrm{CH}\left(\mathrm{CH}_{3}\right)_{2}\right) \mathrm{PP}\right)_{2}\right]$ & $448.8(\mathrm{~S}) \quad 671.1$ \\
\hline$\Delta \lambda^{a}$ & 29.1 \\
\hline
\end{tabular}

(S): Soret band. ${ }^{a} \Delta \lambda$ : Red shifts for the bands of the porphyrins upon the i-SAT complexation.

metry is produced because the ring inversion of the saddled core conformation of the porphyrin is probably fast on the NMR time scale. $^{2-10,17}$

${ }^{13} \mathrm{C}$ NMR spectrum of $\mathrm{H}_{2} \mathrm{~T}\left(4-\mathrm{CH}_{3}\right) \mathrm{PP}$ has been shown six sharp signals $\left(\left(120.5\left(\mathrm{C}_{\text {meso }}\right), 127.8\left(\mathrm{C}_{\mathrm{m}, \mathrm{m}^{\prime}}\right), 137.7\left(\mathrm{C}_{\mathrm{p}}\right), 131.4\right.\right.$ $\left.\left.\left(\mathrm{C}_{\beta}\right), 134.9\left(\mathrm{C}_{\mathrm{o}, \mathrm{o}^{\prime}}\right), 139.7\left(\mathrm{C}_{\mathrm{p}^{\prime}}\right) \mathrm{ppm}\right)\right)$ and a very broad signal (145 ppm) for $\alpha$-carbon in the aromatic region. But ${ }^{13} \mathrm{C}$ NMR spectrum of the sandwich i-SAT complex, $\left[\mathrm{TeCl}_{4}\left(\mathrm{H}_{2} \mathrm{~T}\left(4-\mathrm{CH}_{3}\right)\right.\right.$ $\mathrm{PP})_{2}$ ], shows seven signals related to aromatic regions $(122.5$ $\left(\mathrm{C}_{\text {meso }}\right), 127.8\left(\mathrm{C}_{\beta}\right), 129.2\left(\mathrm{C}_{\mathrm{m}, \mathrm{m}^{\prime}}\right), 137.6\left(\mathrm{C}_{\mathrm{p}^{\prime}}\right), 139.0\left(\mathrm{C}_{\mathrm{o}, \mathrm{o}^{\prime}}\right), 140.4$ $\left.\left(\mathrm{C}_{\mathrm{p}^{\prime}}\right), 146.1\left(\mathrm{C}_{\alpha}\right) \mathrm{ppm}\right)$, Figure 4 . On the other hand, the forma- (b)

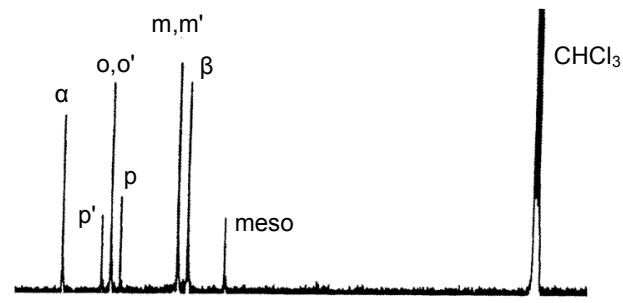

(a)

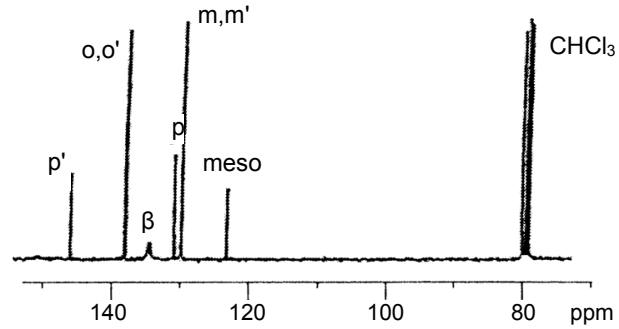

Figure 4. ${ }^{13} \mathrm{C}$ NMR spectra of (a) $\mathrm{H}_{2} \mathrm{~T}\left(4-\mathrm{CH}_{3}\right) \mathrm{PP}$, (b) $\left[\mathrm{TeCl}_{4}\left(\mathrm{H}_{2} \mathrm{~T}(4-\right.\right.$ $\left.\left.\left.\mathrm{CH}_{3}\right) \mathrm{PP}\right)_{2}\right]$.

(b)
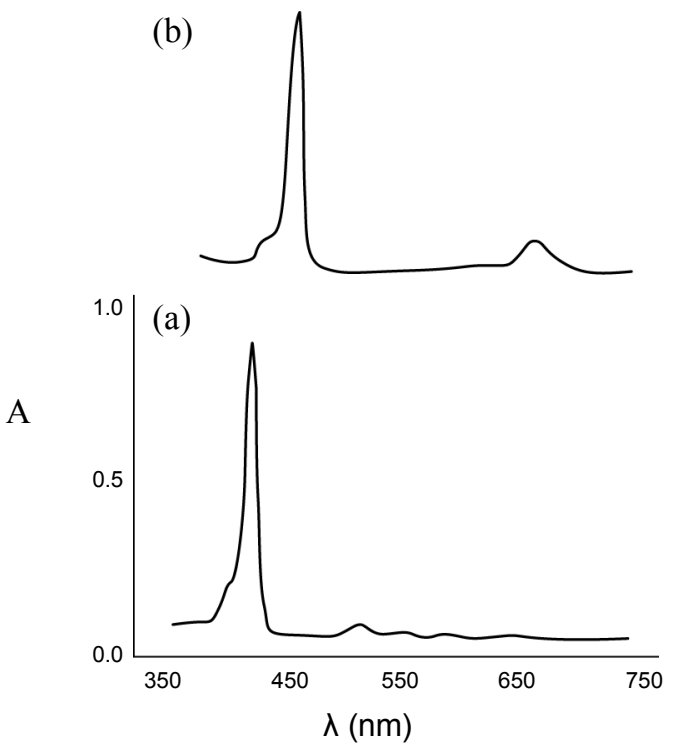

Figure 5. UV-vis spectra of (a) $\mathrm{H}_{2} \mathrm{~T}\left(4-\mathrm{CH}_{3}\right) \mathrm{PP}$, (b) $\left[\mathrm{TeCl}_{4}\left(\mathrm{H}_{2} \mathrm{~T}(4-\right.\right.$ $\left.\left.\left.\mathrm{CH}_{3}\right) \mathrm{PP}\right)_{2}\right]$.

tion of the sandwich i-SAT complex, $\left[\mathrm{TeCl}_{4}\left(\mathrm{H}_{2} \mathrm{~T}\left(4-\mathrm{CH}_{3}\right) \mathrm{PP}\right)_{2}\right]$, sharpens the $\alpha$-carbon and $\beta$-carbon signals in the ${ }^{13} \mathrm{C} N M R$ spectrum and so leads to a small shifts in the other signals. All of these changes are in the same direction to the i-SAT complexation of $\mathrm{H}_{2} \mathrm{~T}\left(4-\mathrm{CH}_{3}\right) \mathrm{PP}$ with uranyl and zirconium(IV) chloride $^{2,3}$ or molecular complexation of the porphyrin with various acceptors. $8,9,14,15$

The UV-vis spectrum of the $\mathrm{H}_{2} \mathrm{~T}\left(4-\mathrm{CH}_{3}\right) \mathrm{PP}$ in chloroform contains five absorption bands in 418.3 (Soret), 518.4, 554.0, $593.0,649.0 \mathrm{~nm}$ region, that upon the SAT complexation with $\mathrm{TeCl}_{4}$ two new bands at 447.1 and $669.4 \mathrm{~nm}$ appear (Table 2), Figure 5. The observed red shifts upon the complexation are because of the out of plane distortion of porphyrin core. This deformation allows a strong interaction between the aryl rings and porphyrin $\pi$-system. ${ }^{2-10,12-18}$ The UV-vis spectral data for other i-SAT complexes of meso-tetraarylporphyrins and tellu- 


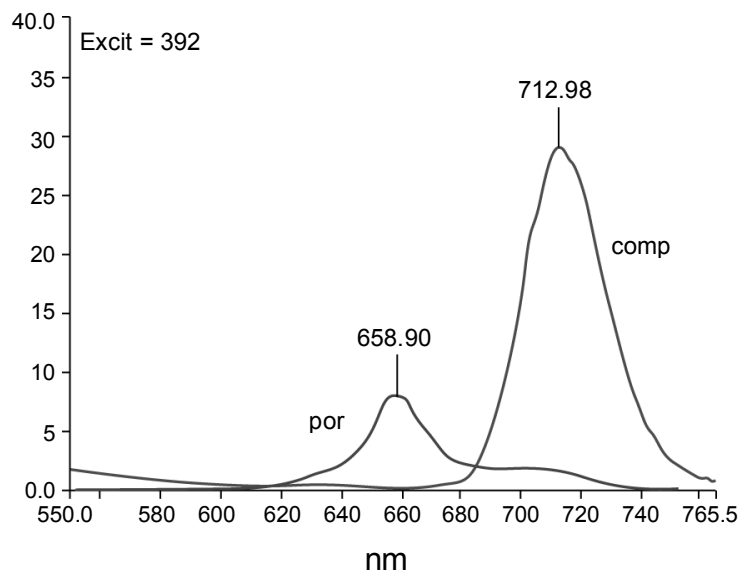

Figure 6. Fluorescence spectra (Intensity-Wavelength (nm)) of $\mathrm{H}_{2} \mathrm{~T}$ $\left(4-\mathrm{CH}_{3}\right) \mathrm{PP}$ and $\left[\mathrm{TeCl}_{4}\left(\mathrm{H}_{2} \mathrm{~T}\left(4-\mathrm{CH}_{3}\right) \mathrm{PP}\right)_{2}\right]$ complex in chloroform $\left(\lambda_{\text {exc }}=\right.$ $392 \mathrm{~nm})$.

rium (IV) chloride are shown in Table 2. The fluorescence spectrum of $\left[\mathrm{TeCl}_{4}\left(\mathrm{H}_{2} \mathrm{~T}\left(4-\mathrm{CH}_{3}\right) \mathrm{PP}\right)_{2}\right]$ (in comparison to the related free base porphyrin, Figure 6) indicates a typical SAT complex. This suggests that deformation in the SAT complexes markedly influences their spectral features.

The spectral similarity between ${ }^{1} \mathrm{H}$ NMR, ${ }^{13} \mathrm{C}$ NMR and UVvis of $\left[\mathrm{TeCl}_{4}\left(\mathrm{H}_{2} \mathrm{~T}(\mathrm{X}) \mathrm{PP}\right)_{2}\right]$ complexes and known i-SAT complexes $^{2-10}$ lead to the proposition of distorted porphyrin cores in all of the species. In the proposed structure four nonocoplanar pyrrole rings tilted alternately up and down and the lone pairs of pyrrolenine nitrogens of two porphyrin core act as the electron donors to one tellurium atom and so, two hydrogen atoms of pyrroles $(\mathrm{N}-\mathrm{H})$ remained still on the porphyrins. In this conformation, the tilting of the pyrrole rings leads to the increasing of the distance between two porphyrin cores and decreasing of the repulsion of those and in result stabilizing in the sandwich i-SAT complexes.

The $\left({ }^{1} \mathrm{H},{ }^{13} \mathrm{C}\right)$ NMR and UV-vis spectral data of the sandwich i-SAT complexes were similar to the related diprotonated species, ${ }^{19-21}$ but the molar conductivities of two species were completely different. This indicates that the i-SAT complexes have been formed and not the diprotonated porphyrin species. The molar conductivity (in acetone solution) showed the i-SAT complexes are not electrolytes, but the molar conductivities of $\left[\mathrm{H}_{4} \mathrm{~T}\right.$ (X)PP $] \mathrm{Cl}_{2}$ in methanol were in accordance with $1: 2$ electrolyte. ${ }^{22}$ For FT-IR $\left(400-4000 \mathrm{~cm}^{-1}\right)$ spectra of the free base mesoteraarylporphyrins observe a N-H stretching band at $3320 \mathrm{~cm}^{-1}$ that did not show considerable changes upon the sandwich i-SAT complexation with $\mathrm{TeCl}_{4}{ }^{23}$ These results were completely in accordance with the proposed structure for the i-SAT complexes in Figure 2. Tellurium(IV) chloride had four chlorine atoms with high electronegativity and could accept four lone pairs of two porphyrin macrocycles with formation of the sandwich i-SAT complexes, [ $\left.\mathrm{TeCl}_{4}\left(\mathrm{H}_{2} \mathrm{~T}(\mathrm{X}) \mathrm{PP}\right)_{2}\right]$.

\section{Conclusion}

The reaction between tellurium(IV) chloride and meso-tetraarylporphyrins leads to formation of new i-SAT complexes, $\left[\mathrm{TeCl}_{4}\left(\mathrm{H}_{2} \mathrm{~T}(\mathrm{X}) \mathrm{PP}\right)_{2}\right]$. The UV-vis, $\left({ }^{1} \mathrm{H}\right.$ and $\left.{ }^{13} \mathrm{C}\right) \mathrm{NMR}$ spectral data indicated that two porphyrin cores are saddled and four pyrrolenine nitrogen atoms of two porphyrin cores act as electron donors to tellurium atom of $\mathrm{TeCl}_{4}$.

Acknowledgments. This work was partly supported by Kashan University Research Council.

\section{References}

1. Kadish, K. M.; Smith, K. M.; Guilard R., Eds., The Porphyrin Handbook; Academic Press: San Diego, 2000; Vols. 1-10.

2. Dehghani, H.; Mansournia, M. R. Polyhedron 2008, 27, 849.

3. Dehghani, H.; Payam, M.; Mansournia, M. R. Polyhedron 2008, 27, 2416.

4. Dehghani, H.; Babaahmadi, M. Polyhedron 2008, 27, 2739.

5. Dehghani, H.; Shaterian, M. Polyhedron 2008, 27, 3263.

6. Dehghani, H.; Shaterian, M. Inorg. Chim. Acta 2009, 362, 2868.

7. Dehghani, H.; Bordbar, M.; Mojiri-Foroushani, M.; Karami, S.; Mansournia, M. R. Inorg. Chim. Acta 2009, 362, 1619.

8. Dehghani, H.; Ansari Sardrood, A. R. Polyhedron 2007, $26,4263$.

9. Dehghani, H.; Ansari Sardrood, A. R. Bull. Chem. Soc. Jpn. 2007, $80,518$.

10. Dehghani, H.; Bakhshayesh, S.; Behnoudnia, F. Inorg. Chim. Acta 2009, 362, 3025 .

11. Gonsalves, A. M. d'A. R.; Varejao, J. M. T. B.; Pereira, M. M. J. Heterocycle. Chem. 1991, 28, 635.

12. Dehghani, H.; Fathi, F. Dyes and Pigments 2008, 77, 323.

13. Dehghani, H.; Fathi, F. J. Porph. Phthal. 2007, 11, 849.

14. Mohajer, D.; Dehghani, H. J. Chem. Soc. Perkin Trans. 22000 , 199.

15. Mohajer, D.; Dehghani, H. Bull. Chem. Soc. Jpn. 2000, 73, 1477.

16. Mohajer, D.; Rayati, S. New J. Chem. 2003, 27, 242.

17. Mohajer, D.; Zakavi, S.; Rayati, S.; Zahedi, M.; Safari, N.; Khavasi, H. R.; Shahbazian, S. New J. Chem. 2004, 28, 1600.

18. Mohajer, D.; Sakhtemanian, E.; Rayati, S.; Zakavi, S. Spectrochimica Acta Part A 2008, 69, 998.

19. Walter, R. I.; Ojadi, E. C. A.; Linschitz, H. J. Phys. Chem. 1993, 97, 13308.

20. Meot-Ner, M.; Adler, A. D. J. Am. Chem. Soc. 1975, 97, 5107.

21. Stone, A.; Fleischer, E. B. J. Am. Chem. Soc. 1968, 90, 2735.

22. Geary, W. J. Coord. Chem. Rev. 1971, 7, 81.

23. Limbach, H. H.; Henning, J.; Stulz, J. J. Chem. Phys. 1983, 78, 5432. 